\title{
Benthic-pelagic coupling and nutrient cycling across an experimental eutrophication gradient
}

\author{
John R. Kelly ${ }^{1}$, Veronica M. Berounsky ${ }^{2}$, Scott W. Nixon ${ }^{2}$ \& Candace A. Oviatt ${ }^{2}$ \\ ${ }^{1}$ Ecosystems Research Center, Corson Hall, Cornell University, Ithaca, New York 14853, USA \\ ${ }^{2}$ Graduate School of Oceanography, University of Rhode Island, Narragansett, Rhode Island 02882-1197, USA
}

\begin{abstract}
Sediment-water exchange rates of dissolved inorganic nitrogen $\left(\mathrm{NH}_{4}^{+}, \mathrm{NO}_{3}^{-}, \mathrm{NO}_{2}^{-}\right)$and phosphorus $\left(\mathrm{PO}_{4}^{3-}\right)$, water column concentrations of both dissolved and particulate forms of $N$ and $P$, and net primary production $\left({ }^{14} \mathrm{C}\right)$ were measured during a summer period in large $\left(13 \mathrm{~m}^{3}\right)$ experimental mesocosms that had been subjected to continuous daily nutrient additions (N, P, Si) for over 1 yr. The concentration of combined dissolved inorganic plus particulate nutrient forms $(N, P)$ was linearly related to the nutrient input rate across a loading range from 596 to $34,100 \mathrm{mmols} \mathrm{N} \mathrm{m}^{-2} \mathrm{yr}^{-1}$. Benthic nutrient regeneration generally increased, although not uniformly, with loading. Average summer fluxes for treatments ranged from about 150 to $1200 \mu \mathrm{mols} \mathrm{NH}_{4}^{+} \mathrm{m}^{-2} \mathrm{~h}^{-1}, 188$ to $989 \mu \mathrm{mols}$ DIN $\mathrm{m}^{-2} \mathrm{~h}^{-1}$, and 8 to $76 \mu \mathrm{mols} \mathrm{PO}_{4}^{3-} \mathrm{m}^{-2} \mathrm{~h}^{-1}$, with highest rates being recorded at the 2 highest loading levels. Benthic nutrient regeneration did not increase in direct proportion to loading, but appeared strongly related to net primary production rates across the enrichment gradient. Comparison, across the experimental gradient, of the external nutrient supply rate with the benthic feedback of dissolved nutrients to the water column indicated that beyond a loading of about 2000 to $5000 \mathrm{mmols} \mathrm{Nm}^{-2} \mathrm{yr}^{-1}$ the water column nutrient dynamics became dominated by the external supply. Results suggest that the importance of benthic-pelagic interactions to biogeochemical and ecological cycles of coastal areas may decrease markedly with nutrient enrichments which exceed the needs of the autotrophic components of the ecosystem.
\end{abstract}

\section{INTRODUCTION}

The ecological importance of biogeochemical interactions between water and sediments in coastal marine ecosystems became widely recognized within the past decade as a result of in situ field research (Nixon 1981, Kemp et al. 1982). Field studies have suggested that the contribution of benthic nutrient regeneration to algal productivity and to nutrient budgets of shallow coastal areas may vary from place to place, but benthic recycling apparently plays a critical role in the nutrition of many systems. Differences among areas may be partially due to differences in physical and morphometric features (e.g. vertical mixing and water depth) of different study areas, but another obvious factor to which the relative importance of benthic recycling must be related is the amount of nutrients supplied from sources outside the ecosystem.

Portions of the chain of ecological events which link external nutrient inputs and benthic feedbacks have been investigated. For example, there is evidence that phytoplankton biomass, phytoplankton production and system metabolism are enhanced with increased nutrient loading (e.g. Boynton et al. 1982, Nixon 1983, Nixon et al. 1984). With increased autochthonous production of particulate organic matter, organic inputs to bottom communities should also increase, thereby influencing rates of benthic nutrient release. Kelly \& Nixon (1984) have shown by controlled experiments that both benthic respiration and nutrient regeneration increase sharply in response to deposition of particulate organic matter. However, one vexing problem is that the primary deposition of organic particles cannot be directly measured in most shallow, well-mixed estuaries and coastal areas. Because of this missing link in the nutrient cycle it is difficult to anticipate the benthic response to nutrient enrichment of the water column.

Recently, a mesocosm experiment involving daily nutrient additions over a long period of time (Nixon et al. 1984) created the opportunity to address the waterto-sediment-to-water nutrient cycle directly. The relation between external nutrient loading and sediment- 
water nutrient exchange was examined under experimental conditions which allowed for a reciprocal coupling between autotrophic water column processes and heterotrophic activity within the bottom sediments. In this paper, we report the net rates of sediment-water exchange of dissolved nitrogen and phosphorus measured during a 3 mo summer period of intensive study. We compare the pattern of benthic fluxes with water column nutrient concentrations, net primary production and the rate of external nutrient delivery. Finally, we comment on the possible ecological and biogeochemical significance of the observations with respect to eutrophication of coastal areas.

\section{METHODS}

The eutrophication experiment. Mesocosms at the Marine Ecosystems Research Laboratory (MERL), located at the Graduate School of Oceanography (GSO) of the University of Rhode Island, were used to establish the experimental eutrophication gradient. The mesocosms are physically scaled to Narragansett Bay, RI, in terms of natural sunlight, temperature ( $\pm 2 \mathrm{C}^{\circ}$ of GSO dock water), tidal mixing (rotating plungers mix the water column on a schedule of $2 \mathrm{~h}$ on and $4 \mathrm{~h}$ off, resuspending bottom sediments as in the Bay) and flushing (GSO dock water is introduced during mixing at near $3.7 \%$ volume exchange $\mathrm{d}^{-1}$, approximating the month-long residence time estimated for the Bay) (Pilson et al. 1977, 1979, Nixon et al. 1980a, Oviatt et al. 1982). Behavior of the tanks in comparison to the Bay has been reported by Pilson et al. (1977, 1979), Elmgren \& Frithsen (1982) and Oviatt et al. (1984). For this experiment, tanks were filled during April 1981 with water $\left(13.1 \mathrm{~m}^{3}\right)$ from off the GSO dock, and sediments (over $30 \mathrm{~cm}$ deep) taken from the usual mid-Narragansett Bay station according to procedures developed in previous experiments (cf. Oviatt et al. 1984).

The rationale for the experimental design and some preliminary findings over the first year of the experiment have been reported (Nixon et al. 1984). Nine mesocosm tanks were available for the experiment. Three tanks served as replicated, unenriched controls. Given the lack of experimental data on coastal eutrophication processes, it was decided that variance estimates within a treatment would be sacrificed in favor of a wider range of loading levels. The 6 remaining tanks were used to create a geometric series of nutrient addition treatments increasing from about $1 \times$ to $32 \times$ the annual dissolved inorganic nutrient loading to Narragansett Bay (Nixon 1981). As the enriched treatments were unreplicated, the objective of the experiment was to describe a pattern of response to enrichment rather than to make statistical inferences between individual treatment levels. The treatments encompassed loading rates measured for a wide variety of U.S. estuaries (Nixon \& Pilson 1983), with the highest treatment similar to the lower Hudson River estuary around $\mathrm{New}$ York City. Solutions of $\mathrm{NH}_{4} \mathrm{Cl}$, $\mathrm{KH}_{2} \mathrm{PO}_{4}$ and $\mathrm{NaSiO}_{3} \cdot 7 \mathrm{H}_{2} \mathrm{O}$ were added daily in the molar ratio measured for sewage effluent to the Bay (12.8 N: 1.0 P: $0.91 \mathrm{Si})$

The tanks were operated as open systems. Inputs therefore included nutrients from feedwater and precipitation (Table 1). We calculated nitrogen and phosphorus inputs (excluding dissolved organics) for both the summer (1982) of our intensive sampling and for the first full year of the experimental nutrient additions (1 June 1981 to 1 June 1982). Feedwater inputs were calculated using measured feedwater volumes for each tank multiplied by the time-weighted (weekly measurements) mean concentration of nutrients in the

Table 1. Inputs of nitrogen and phosphorus in the MERL experiment

\begin{tabular}{|c|c|c|c|c|}
\hline \multirow[b]{2}{*}{ Treatment } & \multicolumn{2}{|c|}{$\begin{array}{l}\text { Annual input (1981-1982) } \\
\left(\mathrm{mmols} \mathrm{m}^{-2} \mathrm{yr}^{-1}\right)^{\circ}\end{array}$} & \multicolumn{2}{|c|}{ 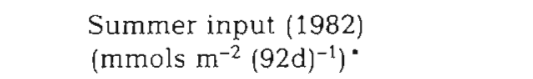 } \\
\hline & Nitrogen & Phosphorus & Nitrogen & Phosphorus \\
\hline $0 \times \cdots$ & 596 & 100 & 72 & 12 \\
\hline $1 \times \cdots$ & 1643 & 181 & 341 & 34 \\
\hline $2 \times$ & 2690 & 263 & 624 & 57 \\
\hline $4 \times$ & 4784 & 425 & 1135 & 95 \\
\hline $8 \times$ & 8972 & 750 & 2199 & 178 \\
\hline $16 \times$ & 17348 & 1400 & 4314 & 342 \\
\hline $32 \times$ & 34100 & 2700 & 8588 & 678 \\
\hline \multicolumn{5}{|c|}{$\begin{array}{l}\text { Table values can be converted to volumetric delivery rates by dividing by } 5 \mathrm{~m} \text {, the water column depth in the tanks } \\
\therefore \text { Inputs from feedwater and precipitation } \\
\text { Daily experimental inorganic nutrient additions to this tank were } 7.57 \text { mmols } \mathrm{N} \mathrm{d}^{-1}\left(=1047 \mathrm{mmols}^{-2} \mathrm{~N} \mathrm{~m}^{-1}\right) \text {. Other } \\
\text { treatments received the indicated multiple of this value, at the N:P:Si ratio given in the text }\end{array}$} \\
\hline
\end{tabular}


feedwater. Nutrient forms included measured dissolved nutrients $\left(\mathrm{NH}_{4}^{+}, \mathrm{NO}_{3}^{-}+\mathrm{NO}_{2}^{-}, \mathrm{PO}_{4}^{3-}\right)$ and estimated particulate nutrients (converted from weekly $\mathrm{Chl}$ a measurements using $\mathrm{C}: \mathrm{Chl} a=30$ by weight, $\mathrm{C} / \mathrm{N}=$ 6.625 by atoms and $\mathrm{C} / \mathrm{P}=106$ by atoms). Particulate $\mathrm{N}$ was about $30 \%$ of the summer feedwater input and $14 \%$ of the annual feedwater input. Particulate $P$ inputs were about $10 \%$ of the feedwater inputs over both periods. Rainfall values were taken from Nixon \& Pilson (1984) for the annual period and calculated using data of Nixon (1983) for summertime. Rainfall inputs were less than $15 \%$ of the non-experimental inputs. The difference between the $0 \times$ control (where total input equals that only from feedwater and rainfall) and the other treatments (Table 1) represents the geometrically-increasing series of experimental nutrient additions. Non-experimental inputs represented a rapidiy decreasing fraction of the total inputs across the experimental enrichment gradient; the fraction differed slightly between $\mathrm{N}$ and $\mathrm{P}$ and between the annual and summer periods because of differences in the N/P ratio of feedwater plus precipitation (about $6: 1$, but seasonally variable) and experimental inputs $(12.8: 1)$. Thus, the total inputs do not represent a geometric series, and there is some difference in the total N/P delivery ratio across the gradient. Throughout this paper, the total annual or summer input indicated in Table 1 is used to represent the abscissa of a treatment; however, treatments are identified based on the experimental enrichment level (i.e. $0 \times, 1 \times, 2 \times \ldots$ $32 \times$ ) to be consistent with other papers describing results of this experiment.

Measurements reported in this paper were made after 1 yr of continuous daily enrichments, during the summer of 1982. We looked intensively across a welldeveloped eutrophication gradient during a season when the interaction between water column and sediment nutrient cycles normally (in Narragansett Bay) reaches a maximum due to high rates of primary production and high rates of benthic regeneration (Furnas et al. 1976, Nixon et al. 1976, 1980b). Other papers report other aspects of the experiment (Berounsky \& Nixon in press, Seitzinger \& Nixon in press, Oviatt et al. unpubl.). Synthesis papers will soon be written.

Sampling and analytical procedures. Three benthic flux measurements were made (Table 2). The MERL in situ benthic respirometer, developed by the senior author and described by Oviatt et al. $(1982,1984)$ and Hunt (1983), was lowered into each tank to cover the entire sediment community. Flux methodology was similar to that used in situ in Narragansett Bay (Nixon et al. 1976, 1980b) and in laboratory sediment microcosms (Kelly 1983, Kelly \& Nixon 1984, Kelly 1984). The chamber enclosed about $14.5 \mathrm{~cm}( \pm 1.5 \mathrm{~cm}$, varying with the depth of sediment originally loaded into
Table 2. Sampling schedule for nutrients

\begin{tabular}{|lll|}
\hline Sampling dates & Temperature & Measurement \\
\hline 27 Jun to 3 Jul 82 & $19.3 \pm 0.6^{\circ} \mathrm{C}$ & Water column \\
27 Jun to 3 Jul 82 & $19.3 \pm 0.6^{\circ} \mathrm{C}$ & Benthic flux \\
19 Jul to 23 Jul 82 & $20.7 \pm 0.7^{\circ} \mathrm{C}$ & Benthic flux \\
15 Aug to 20 Aug 82 & $21.8 \pm 1.0^{\circ} \mathrm{C}$ & Water column \\
15 Aug to 20 Aug 82 & $21.8 \pm 1.0^{\circ} \mathrm{C}$ & Benthic flux \\
\hline
\end{tabular}

each sediment container) of water (about 360 l) overlying the sediment. Initial and final water samples were withdrawn from the chamber by siphon after mixing the enclosed water to homogeneity with a stirring rod operated manually by a pole extending to the surface of the tank. Fluxes were calculated assuming linear concentration changes over time and were corrected for changes in pelagic control bottles. Incubations typically lasted about $3 \mathrm{~h}$, the length of time being chosen to maximize analytical detection of nutrient concentration changes while only allowing oxygen levels to fall to about $70 \%$ of their initial ambient values.

For benthic fluxes, several dissolved forms of nitrogen and phosphorus were measured. We analyzed for dissolved inorganic nitrogen $\left(\mathrm{DIN}=\mathrm{NH}_{4}^{+}+\mathrm{NO}_{3}^{-}+\right.$ $\mathrm{NO}_{2}^{-}$). Ammonium $\left(\mathrm{NH}_{4}^{+}\right)$was determined following Solorzano (1969), modified for a $10 \mathrm{ml}$ sample, and fixed immediately. Samples for other forms were also filtered (Gelman A/E glass fiber), but then frozen in polyethylene bottles and thawed for analysis. Nitrate plus nitrite $\left(\mathrm{NO}_{3}^{-}+\mathrm{NO}_{2}^{-}\right)$were analyzed using standard automated colorimetric procedures (Lambert \& Oviatt 1983). Phosphate $\left(\mathrm{PO}_{4}^{3-}\right)$ and dissolved organic phosphorus (DOP) were analyzed following Strickland \& Parsons (1968). In June, dissolved organic nitrogen (DON) was measured (Valderrama 1981). DON, $\mathrm{NH}_{4}^{+}$, $\mathrm{PO}_{4}^{3-}$ and $\mathrm{DOP}$ were analyzed in triplicate; only a single determination of initial and final $\mathrm{NO}_{3}^{-}+\mathrm{NO}_{2}^{-}$ was made.

Dissolved and particulate $\mathrm{N}$ and $\mathrm{P}$ were measured in the water column at the first and last benthic flux measurements (Table 2). Total N (TN) and P (TP) were determined on whole water samples, DON and DOP on filtered water, and particulate $\mathrm{N}(\mathrm{PN})$ and $\mathrm{P}(\mathrm{PP})$ taken as the difference between total and dissolved; analyses followed Valderrama (1981). Inorganic forms were determined as for benthic fluxes. Triplicate analyses were performed. Samples were taken during the mixing cycle in the tanks and represent depth-integrated averages. For the June sampling, water column measurements were made $1 \mathrm{~d}$ prior to, as well as the day of (but prior to) the benthic flux measurement. At the August measurements we analyzed only the samples taken the day of the benthic flux.

The upper 4 treatments had very high water column 
Table 3. Analytical precision of chemical determinations. Average standard deviations (in $\mu M$ ) on triplicate analyses of a given form, calculated from data for water column and initial benthic flux concentrations. n varies from 18 to 45 . Low tanks are $0 \times$ through $2 \times$ treatments, samples were not diluted. High tanks are $4 \times$ through $32 \times$ treatments, diluted 1:10 before analysis. Entries give analytical variability as average for each group; the higher concentrations in each group have slightly higher, and the lower concentrations in each group, slightly lower values than the average

\begin{tabular}{lcccccccc}
\hline & & & Form & & & \\
Treatment & $\mathrm{TN}$ & $\mathrm{DON}$ & $\mathrm{NH}_{4}$ & $\mathrm{NO}_{3+2}$ & $\mathrm{TP}$ & $\mathrm{PO}_{4}{ }^{3-}$ \\
\hline Low tanks & \pm 1.77 & \pm 1.19 & \pm 0.12 & \pm 0.06 & \pm 0.04 & \pm 0.05 & \pm 0.05 \\
High tanks & \pm 5.46 & \pm 4.55 & \pm 1.09 & \pm 0.21 & \pm 0.37 & \pm 0.65 & \pm 0.43 \\
\hline
\end{tabular}

concentrations. It was necessary to dilute samples (usually $1: 10$ with deionized water or artificial seawater of near-zero concentration of the particular nutrient form) to bring concentrations within the normal range of standard chemical analyses. Because of dilution, the analytical uncertainty was greater in the more enriched tanks (Table 3). Therefore, detection of concentration changes within the benthic respirometer became difficult at the upper end of the gradient. An error analysis is thus provided with the flux results. Benthic fluxes were calculated using the mean concentrations of triplicate initial, final and control samples. Ranges in the flux estimate were obtained by making the same calculations using $\pm 1 \mathrm{SD}$ about the mean concentrations.

In addition to nutrient measurements, estimates of net primary production were made. Net production was measured as the incorporation of ${ }^{14} \mathrm{C}$-labeled bicarbonate added to incubation bottles suspended in the tanks during short-term midday (1000 to $1400 \mathrm{~h}$ ) incubations. Detailed discussion of the standard ${ }^{14} \mathrm{C}$ productivity methods are given in Lambert \& Oviatt (1983). Values presented in this paper represent the average of biweekly measurements through the summer period in all 9 mesocosms. Values are expressed as hourly rates of daytime carbon production; conversion from hourly rates to net daily production is complicated (Oviatt et al. 1981, unpubl.).

Turnover rate calculations. A simple way to express the interaction of water column and sediment nutrient cycles is to compare the magnitude of measured nutrient release by the benthos to the measured mass of nutrients in the water column. A turnover rate was calculated:

$$
\mathrm{TR}=\frac{\text { Benthic flux (DIN or } \left.\mathrm{PO}_{4}^{3-}\right)}{\text { Water column mass }\left(\mathrm{DIN}+\mathrm{PN} \text { or } \mathrm{PO}_{4}^{3-}+\mathrm{PP}\right)}
$$

Turnover rates for Narragansett Bay and other coastal areas have been calculated using dissolved inorganic nutrients (Hale 1974, Elderfield et al. 1981, Aller \& Benninger 1981). There are rapid conversions between dissolved and particulate forms as a result of biological activity in the water. Because we estimated both dissolved inorganic and particulate pools, it was appropriate to include the combined mass. Dissolved organic fluxes and pools could also be included in the calculation; $_{i}$ however, fluxes were small and uncertain, and only a small, but also an uncertain, fraction of the dissolved organic pool seems labile so we chose not to include the dissolved organics. Often, a significant fraction of the nutrient pool was held within particles consideration of only the dissolved forms can overestimate the importance of the benthic flux in relation to the mass of biologically active nutrients in the water. Under conditions where particulate inputs to the sediments are about equal to the dissolved release rates and there is little net accumulation in the sediments (e.g. mid-Narragansett Bay over an annual cycle: Kelly \& Nixon 1984), the turnover rate would approximate the cycle of an element from the water column to the sediments and back to the water, and not merely represent a 'replacement' of the water column mass. We refer to the calculated sediment-water turnover rate as 'internal' as it is due to a recycling process within the ecosystem. The calculation ignores water column recycling processes as it involves only the 'larger, slower' benthic-pelagic recycling loop. Presumably the pelagic nutrient turnover rates are an order of magnitude faster (Furnas et al. 1976, Nixon \& Pilson 1983), but estimates are not available for the experiment. We compare this internal turnover rate with an 'external' turnover rate, calculated by substituting the tank nutrient loading rates for the summer (Table 1) for benthic fluxes in the above equation. The comparison indicates the quantitative importance of benthic nutrient regeneration versus the external nutrient supply, but also illustrates the rate at which the water column concentrations can change as a result of various fluxes to (and from) it. 


\section{RESULTS AND DISCUSSION}

\section{Net sediment-water exchange rates}

\section{General pattern across the loading gradient}

Net sediment-water exchange rates of dissolved nutrients generally increased as a function of increased nutrient loading. However, there was not a uniform increase across the enrichment gradient (Fig. 1). Changes in benthic nutrient regeneration rates were slight in comparison to the change in the magnitude of nutrient input across the experimental enrichment gradient. While exchange rates of $\mathrm{NH}_{4}^{+}$and $\mathrm{PO}_{4}^{3-}$ were related to each other (Fig. 1, Table 4 ), they were clearly not linearly related to nutrient loading.

Nutrient fluxes were roughly proportional to $1 / 3$ to $2 / 5$ the power of loading (Fig. $1 \& 2$ ). From controls to the $16 \times$ treatment, almost a 30 -fold increase in annual nitrogen loading (Table 1 ), benthic fluxes increased by a factor less than 10 - average summer values $(0 \times$ to $16 \times$ ) ranged from about 8 to $76 \mu \mathrm{mols} \mathrm{PO}_{4}^{3-} \mathrm{m}^{-2} \mathrm{~h}^{-1}$ and from 150 to almost $1200 \mu \mathrm{mols} \mathrm{NH}_{4}^{+} \mathrm{m}^{-2} \mathrm{~h}^{-1}$ (Table 4). The $\mathrm{NH}_{4}^{+}$and $\mathrm{PO}_{4}^{3-}$ fluxes appeared to be lower at the $32 \times$ treatment than at $16 \times$; this is discussed below. Omitting the $32 \times$ treatment, the slope of a $\log -\log$ regression of $\mathrm{NH}_{4}^{+}$flux vs annual $\mathrm{N}$ loading also indicated the departure from linearity (i.e. slope $=$ 1.0): $\log \left(\mathrm{NH}_{4}^{+}\right.$flux $)=0.969+0.438 \log (\mathrm{N}$ input $)$, $\mathrm{r}^{2}=0.76, \mathrm{n}=8$ (Fig. 2). Total dissolved inorganic nitrogen (DIN) flux generally increased, on the average, across the entire treatment gradient. Average DIN flux rates ranged from 188 to $989 \mu$ mols DIN m ${ }^{-2} \mathrm{~h}^{-1}$ from the controls to the $32 \times$ treatment (Fig. 2, Table 4), an increase in annual $\mathrm{N}$ loading by a factor of 57 . Omitting a large $\mathrm{NO}_{3}^{-}+\mathrm{NO}_{2}^{-}$uptake measured at one of the 3 flux measurements in the $8 \times$ treatment (Fig. 2), a direct relation between DIN flux and annual loading was indicated by the regression: $\log ($ DIN flux $)=1.17$ $+0.374 \log (\mathrm{N}$ input $), r^{2}=0.74, n=7$.

\section{Coupling water column and benthic processes}

Across the gradient, net primary production increased by a factor of 10 - from a summer average of $33 \mathrm{mg} \mathrm{C} \mathrm{m}{ }^{-2} \mathrm{~h}^{-1}$ (average values of 28.4, 31.0, $39.8 \mathrm{in}$ the 3 control tanks) to $334 \mathrm{mg} \mathrm{C} \mathrm{m}^{-2} \mathrm{~h}^{-1}$ at $32 \times$. Net primary production thus increased only slightly more than benthic fluxes; summer rates were roughly proportional to about $1 / 2$ the power of annual loading: $\log (\mathrm{NPP})=0.061+0.508 \log (\mathrm{N}$ input $), \mathrm{r}^{2}=0.78$ $\mathrm{n}=9$ (Fig. 2). The slope of the relation decreases slightly if summer loading rates are used: $\log (\mathrm{NPP})=$ $0.691+0.414 \log (\mathrm{N}$ input $), \mathrm{r}^{2}=0.74, \mathrm{n}=9$. However, as with fluxes, the pattern of productivity with increasing enrichment was not a uniform increase; variation about the general trend of production with loading explained some of the variation around the generally increasing trend in benthic fluxes. For example, production and benthic nitrogen remineralization were related, with exceptions, on a tank-by-tank basis (Fig. 2). Structural regressions, appropriate when neither variable is 'independent' or measured without


Fig. 1 Net sediment-water exchange rates vs annual $N$ loading. Three flux measurements in 1 control and 6 treatments (points slightly offset for display) were made through the summer; treatments are designated along the $\mathrm{x}$-axis. Values above zero represent net release to the water, negative values indicate uptake by sediment. Points represent the fluxes estimated using the mean concentrations; bars around points represent range of the flux estimate (see 'Methods'). Points without bars have errors smaller than the radius of the circle. Curves originating from control tank values indicate the expected increase in fluxes if rates increased in $1: 1$ proportion to loading 
Table 4. Benthic fluxes across treatments, $\mu \mathrm{mol} \mathrm{m} \mathrm{m}^{-2} \mathrm{~h}^{-1}$. Average of 3 measurements through summer (not including analytical uncertainty for each measurement: see Fig. 1); parentheses indicate SD of those 3 values; positive values represent a net release to the water column by the sediment community, negative values represent uptake by the sediment

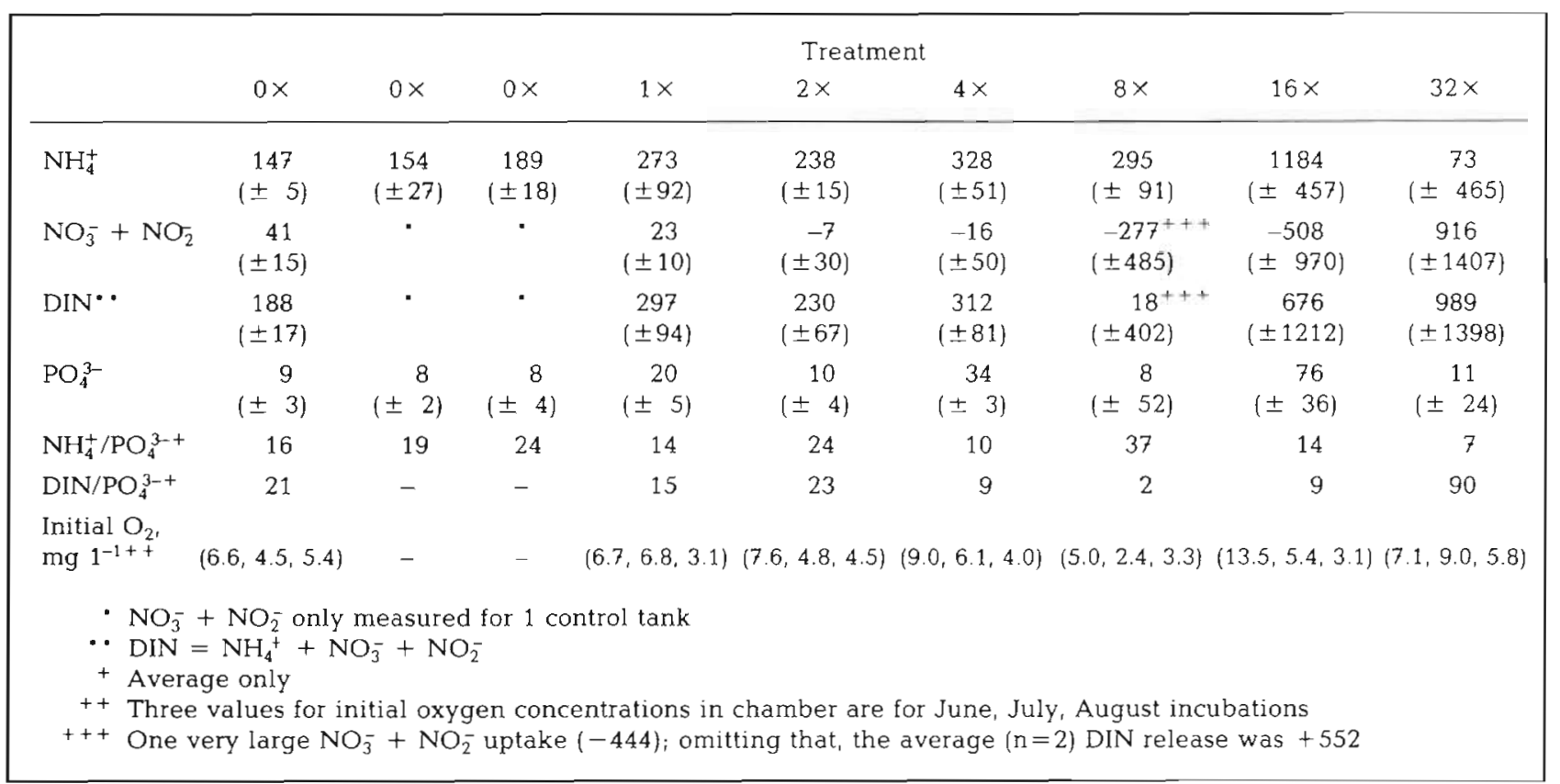

error (see Moran 1971), between nitrogen fluxes and net production gave evidence for linear relations: $\mathrm{NH}_{4}^{+}$ flux $=4.8 \mathrm{NPP}-0.3, \mathrm{r}^{2}=0.99, \mathrm{n}=8$ (omits $32 \times$ ) and DIN flux $=2.5 \mathrm{NPP}+116, \mathrm{r}^{2}=0.99 \mathrm{n}=7$ (omits July value for $8 \times$ ).

The finding of a direct relation is consistent with other recent studies on benthic-pelagic coupling. In benthic microcosm experiments using the mid-Narragansett Bay bottom community, nitrogen release was approximately a linear function of particulate organic deposition rates (Kelly \& Nixon 1984). Additionally, Nixon (1981) observed a linear relation between productivity and benthic metabolism, measured as oxygen uptake, for a number of shallow coastal areas and across a range of annual productivity similar to that encountered in this eutrophication gradient experiment. There would seem to be several implications of the consistency of these findings.

A relatively consistent, linear relation between water column production and remineralization of organic matter within bottom sediments seems surprising given the large changes observed in the composition and trophic structure of both the pelagic and benthic communities as a consequence of different loading levels (Nixon et al. 1984). Changes included alteration of benthic macrofaunal species, numbers and biomass. In spite of macrofaunal changes, a consistent relation might arise if the majority of sedirnent organic remineralization occurs quickly after deposition, and the sediment-water nutrient interaction remains primarily a surface phenomenon (Kemp et al. 1982, Kelly \& Nixon 1984) controlled by the supply of settling organic matter (Pamatmat 1971, Hargrave 1973). It might also be that the lability of the autochthonous particles fueling benthic processes does not differ a great deal as a function of autotrophic species replacements occurring from water column enrichments. These notions deserve further scrutiny, because there may be important exceptions. Nevertheless, a certain measure of functional redundancy in nutrient cycling processes, independent of changes in the biological community, seems indicated.

\section{Variability in flux rates}

A striking aspect of the nutrient flux data was the pattern of variability across the gradient (Fig. 1). For lower treatments $(0 \times$ to $4 \times)$ the variation through the summer within a treatment often exceeded errors associated with analytical uncertainties. Average coefficients of variation were not large, ranging from 14 to 24 to $30 \%$ for $\mathrm{NH}_{4}^{+}, \mathrm{DIN}$ and $\mathrm{PO}_{4}^{3-}$ respectively. In contrast, rates at the highest treatments were quite variable. For example, at low loading rates nitrate plus nitrite fluxes were relatively consistent, and less than $20 \%$ of the DIN flux. At high treatments there were occasional high rates of $\mathrm{NO}_{3}^{-}+\mathrm{NO}_{2}^{-}$exchange, including both fluxes into and out of the sediments, varying in direction and magnitude among measurements within a given tank. Variations in both direction 




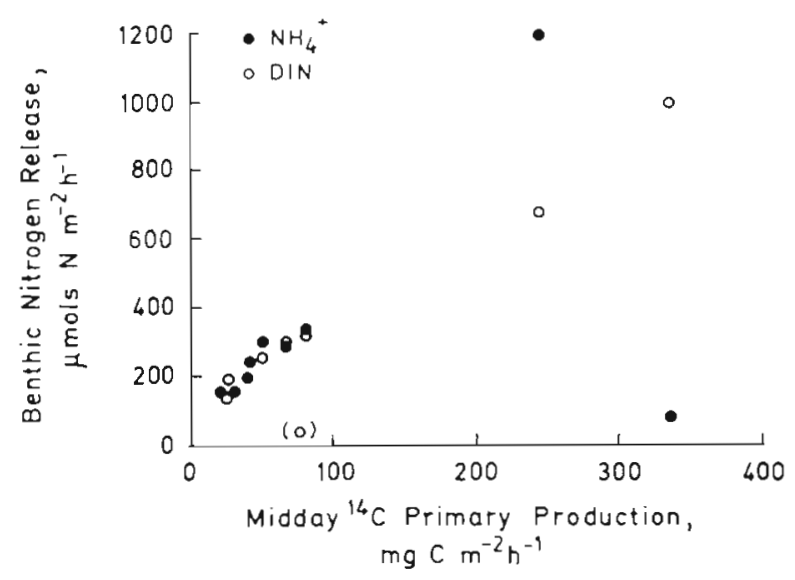

and magnitude of $\mathrm{NO}_{3}^{-}$or $\mathrm{NO}_{2}^{-}$fluxes have also been noted in field studies (Nixon et al. 1976, Boynton et al. 1980 ) and result from nitrification-denitrification processes in sediments (Seitzinger \& Nixon in press). In addition, the coefficient of variation of both $\mathrm{NH}_{4}^{+}$and $\mathrm{PO}_{4}^{3-}$ exchange rates also occasionally exceeded $100 \%$ at the higher treatments (Table 4 ).

Temporal variability in fluxes can be caused by the activity of macrofauna (Henricksen et al. 1980, McCaffrey et al. 1980, Aller 1982, Kelly 1983), and by shortterm variability in pelagic production (Hunt 1983), even when temperatures are relatively constant. While some such temporal variability undoubtedly occurred, we could not reliably address this issue because a good deal of variability was attributable to the measurement itself. Uncertainties in the flux estimates arise from using a 2-point (initial-final) incubation technique rather than a time series, but more importantly from trying to detect small changes in concentrations relative to the high background levels at the upper treatments. The latter problem became exacerbated by the
Fig. 2. Benthic nitrogen release and midday ${ }^{14} \mathrm{C}$ pelagic production. Top: benthic nitrogen release $\left(\mathrm{NH}_{4}^{+}, \mathrm{DIN}\right)$, average summer values per treatment (from Table 4 ). The dotted line to the point for the $8 \times$ treatment for DIN includes all 3 summer measurements, the solid line to the point for the $8 \times$ treatment includes only 2 measurements, omitting a July value of a large sediment $\mathrm{NO}_{3}^{-}+\mathrm{NO}_{2}^{-}$uptake. Production and $\mathrm{NH}_{4}^{+}$flux were measured in all 9 mesocosms. DIN flux was only measured in 1 control mesocosm. Bottom: data as in top panel. Parenthetical point for DIN same as dotted line to point for $8 \times$ treatment dilutions necessary to perform standard chemical analyses, introducing considerable uncertainty in $\mathrm{NH}_{4}^{+}$ and $\mathrm{PO}_{4}^{3-}$ rate estimates at $16 \times$ and $32 \times$ (Fig. 1). Unfortunately, we did not take replicate $\mathrm{NO}_{3}^{-}+\mathrm{NO}_{2}^{-}$ samples and cannot assess their methodological uncertainties. However, we suspect the errors to be less acute than with $\mathrm{NH}_{4}^{+}$as the relative analytical error was lower (Table 3), in part because $\mathrm{NO}_{3}^{-}+\mathrm{NO}_{2}^{-}$ concentrations did not increase as much as $\mathrm{NH}_{4}^{+}$from the increased $\mathrm{NH}_{4}^{+}$loading (Nixon et al. 1984, Berounsky \& Nixon in press).

For $\mathrm{NH}_{4}^{+}$fluxes, as well as for $\mathrm{PO}_{4}^{3-}$, the problem at the upper treatment levels is similar to the difficulty of measuring dissolved organic exchange rates against high concentration backgrounds observed in the water even under unenriched conditions (Nixon 1981). A June measurement failed to detect a significant exchange of DON between water and sediments in any treatment, although rates would have to have exceeded 50 to $100 \mu \mathrm{mols}$ DON m $\mathrm{m}^{-2} \mathrm{~h}^{-1}$ to be convincing. With DOP, there were only 6 cases (of 27 summer 
measurements) where fluxes were significantly different from zero net exchange; however, none were significantly greater than about 5 umols DOP $\mathrm{m}^{-2} \mathrm{~h}^{-1}$ into or out of the sediments, nor was there any systematic pattern with treatment or time.

If $\mathrm{NH}_{4}^{+}$and $\mathrm{PO}_{4}^{3-}$ release rates had increased in a linear fashion with loading they would have been easily detectable at $32 \times$, even given the considerable analytical uncertainties. Flux rates at $32 \times$, except $\mathrm{NO}_{3}^{-}+\mathrm{NO}_{2}^{-}$(Table 4), never appeared different from no net exchange. Rates may have been suppressed; there were frequent low oxygen levels in the water column and even a brief anoxic period between the July and August flux measurements (MERL unpubl.). On the other hand, similar low $\mathrm{O}_{2}$ concentrations were observed during flux measurements in all of the other treatments (Table 4) and it was not possible, for the most part, to suggest that the $32 \times$ and $16 \times$ treatments were ever significantly different. Flux estimates past the $16 \times$ treatment thus remain problematic.

\section{Changes in nutrient cycling with enrichment}

Water column enrichment

Dissolved inorganic and particulate forms of $N$ and $P$ increased with loading. The concentrations of DIN $\left(\mathrm{NH}_{4}^{+}+\mathrm{NO}_{3}^{-}+\mathrm{NO}_{2}^{-}\right)$and $\mathrm{PO}_{4}^{3-}$ reached at the upper end of the gradient (Table 5) were comparable to highly enriched field situations summarized by Nixon \& Pilson (1983). We saw no evidence for any consistent increases across the gradient in dissolved organic forms of $\mathrm{N}$ and $\mathrm{P}$, which generally varied from about 15 to $30 \mu \mathrm{M}$ DON and 0.0 to $0.6 \mu \mathrm{M}$ DOP - values mostly typical of Narragansett Bay conditions. Changes across the gradient in total nitrogen (TN) from 20 to near $430 \mu \mathrm{M}$ and total phosphorus (TP) from near 1 to $35 \mu \mathrm{M}$ were caused by changes in DIN $+\mathrm{PN}$ and $\mathrm{PO}_{4}^{3-}+\mathrm{PP}$ (Fig. 3).
The particulate fraction showed a non-linear increase across the gradient. PN and PP changes were related. Individual $\mathrm{PN} / \mathrm{PP}$ ratios varied from about 6 to $19(\bar{X}=11, n=14)$, but on the whole the stoichiometry approximated the Redfield model for organic matter (structural regression, $\mathrm{PN}=16.9 \mathrm{PP}$ $-5.2, r^{2}=0.82, n=14$ ). The average concentrations of $\mathrm{PN}$ and PP were related to about $3 / 5$ to $4 / 5$ the power of annual loading (Fig. 3). Predictive regressions were as follows: $\log (\mathrm{PN})=1.34+0.60 \log (\mathrm{N}$ input $), \mathrm{r}^{2}=$ $0.77, n=7$ and $\log (P P)=-2.21+0.79 \log (P$ input $)$, $r^{2}=0.88, n=7$. The fraction of water column $N$ and $P$ in suspended particles decreased with nutrient loading - it was over $20 \%$ under unenriched conditions and less than $10 \%$ at the upper end of the loading gradient (Table 5).

The combined particulate and dissolved inorganic fraction (DIN + PN and $\mathrm{PO}_{4}^{3-}+\mathrm{PP}$ ) was a linear function of the annual nutrient load. $\mathrm{N}$ and $\mathrm{P}$ water column concentrations were thus controlled by their respective loading rates (Fig. 3). Predictive regressions of the combined fraction concentration vs annual loading were as follows: $\log (\mathrm{DIN}+\mathrm{PN})=-2.19+1.08$ $\log (\mathrm{N}$ input $), \mathrm{r}^{2}=0.99$ and $\log \left(\mathrm{PO}_{4}^{3-}+\mathrm{PP}\right)=-2.26$ $+1.15 \log \left(P\right.$ input), $r^{2}=0.98$. Phosphorus concentration could be similarly expressed as a direct function of $\mathrm{N}$ input. Construction of $95 \%$ confidence intervals for the slopes of Log:Log regressions of concentration vs annual $\mathrm{N}$ inputs showed that the slopes did not differ significantly from 1.0. Using a standard least squares predictive regression and a t-distribution for the slope interval estimate, $95 \%$ confidence intervals on the slope were: for $\log (D I N+P N)$ vs $\log (N$ input $), b=$ $1.08 \pm 0.12$, and for $\log \left(\mathrm{PO}_{4}^{3-}+\mathrm{PP}\right)$ vs $\log (\mathrm{N}$ input $)$, $\mathrm{b}=0.95 \pm 0.15$. Using a structural regression (perhaps more appropriate where both $\mathrm{x}$ and $\mathrm{y}$ values have some error) and interval estimate of Gleser (1982), assuming approximately equal variance in $x$ and $y, 95 \%$ confidence intervals on the slope were: for $\log (D I N+P N) v s \log (N$ input $), b=1.07 \pm 0.07$, and for $\log \left(\mathrm{PO}_{4}^{3-}+\mathrm{PP}\right)$ vs $\log (\mathrm{N}$ input $), \mathrm{b}=0.95 \pm 0.09$.

Table 5. Particulate and dissolved inorganic nutrient concentrations. Average summer values in water column

\begin{tabular}{|c|c|c|c|c|c|c|}
\hline Treatment & $\begin{array}{l}\mathrm{DIN} \\
\mu \mathrm{M}\end{array}$ & $\begin{array}{l}\mathrm{PN} \\
\mu \mathrm{M}\end{array}$ & $\begin{array}{c}\% \text { PN of } \\
(D I N+P N)\end{array}$ & $\begin{array}{l}\mathrm{PO}_{4}^{3-} \\
\mu \mathrm{M}\end{array}$ & $\begin{array}{l}\mathrm{PP} \\
\mu \mathrm{M}\end{array}$ & $\begin{array}{c}\% \mathrm{PP} \text { of } \\
\left(\mathrm{PO}_{4}^{3-}+\mathrm{PP}\right)\end{array}$ \\
\hline $0 \times$ & 3.7 & 1.8 & 33 & 0.91 & 0.22 & 19 \\
\hline $1 \times$ & 17.2 & 5.6 & 25 & 2.03 & 0.55 & 21. \\
\hline $2 x$ & 26.9 & 5.3 & 16 & 2.23 & 0.54 & 20 \\
\hline $4 \times$ & 44.2 & 7.9 & 15 & 4.56 & 0.46 & 9 \\
\hline $8 x$ & 130.2 & 5.2 & 4 & 11.12 & 0.71 & 6 \\
\hline $16 x$ & 254.7 & 33.0 & 11 & 27.80 & 2.30 & 8 \\
\hline $32 \times$ & 376.7 & 19.2 & 5 & 38.9 & 3.66 & 9 \\
\hline
\end{tabular}



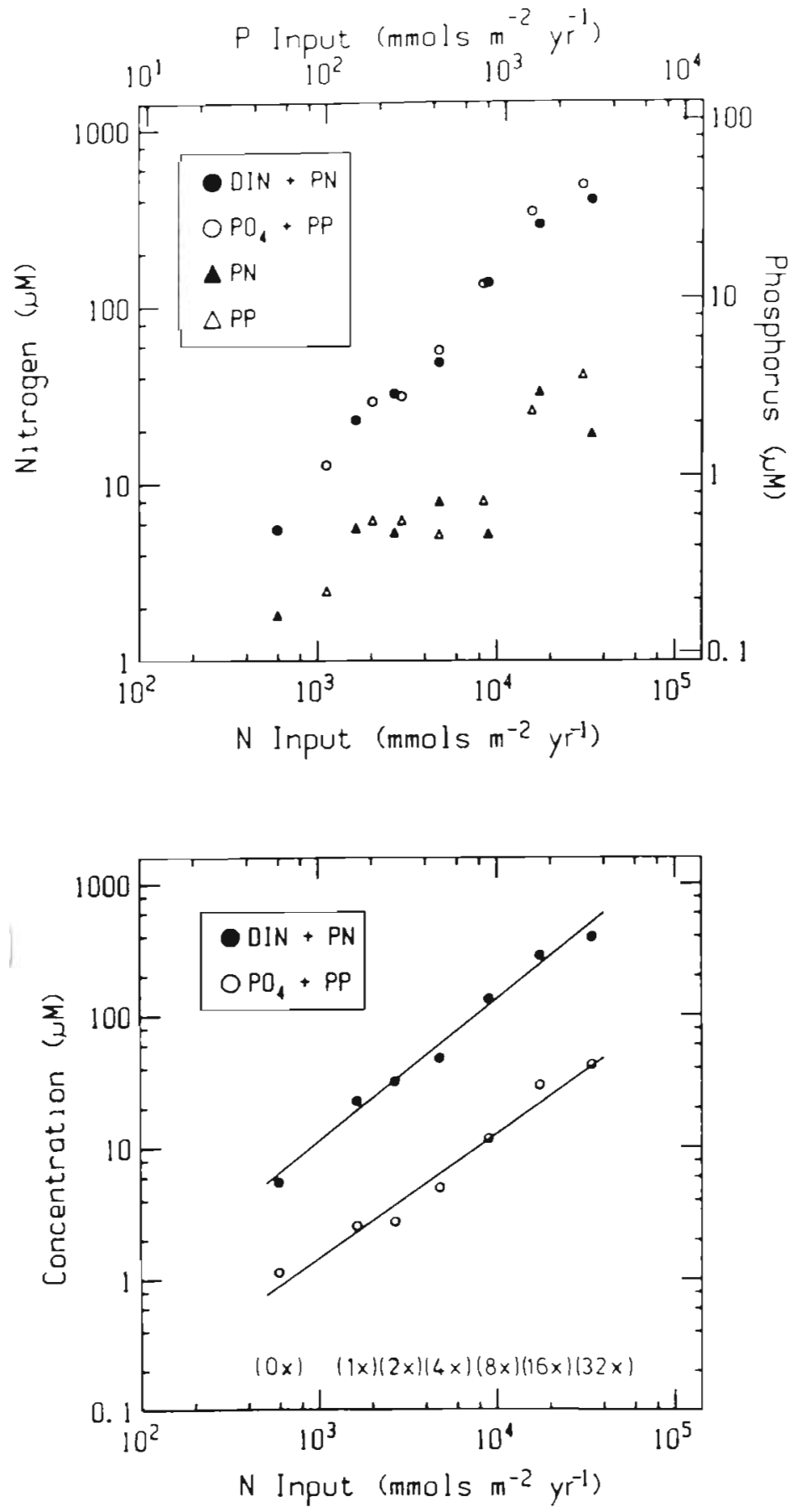

Fig. 3. Water column nutrient concentrations vs annual loading. Top: Concentration (from Table 5) of each treatment vs nutrient input, $\mathrm{N}$ vs $\mathrm{N}$ input and $\mathrm{P}$ vs $\mathrm{P}$ input. The ordinate and abscissa have been scaled to reflect the experimental input ratio, $12.8 \mathrm{~N}: 1 \mathrm{P}$; where paired $\mathrm{N}$ and $\mathrm{P}$ points for an individual treatment differ in the X-direction the loading ratio (see Table 1) deviates from 12.8:1 and where points differ in the $Y$-direction, the N/P concentration ratio deviates from $12.8: 1$. With some individual exception (notably control tank, lowest values), the N/P concentration ratio was close to 12.8: 1. Bottom: Same data as top panel with both DIN + PN and $\mathrm{PO}_{4}^{3-}+\mathrm{PP}$ plotted vs $\mathrm{N}$ input. Note that treatment designations $(0 \times, 1 \times, \quad 32 \times)$ are indicated along the $x$-axis
Nutrient budgets: inputs and outputs from the tanks

That the combined water column fraction varied almost 1 to 1 with nutrient inputs implied that the tanks were not strong sinks for $\mathrm{N}$ and $\mathrm{P}$. We were able to suggest that water column retention of the nutrients added over the first year of the experiment (June 1981 to June 1982) was small (Table 6). Only 5 to $10 \%$ of the added nutrients had accumulated in the water even though this time period included the initial, distinctly non-steady-state period when there was a rapid rise in water concentrations. A very rough calculation for annual sediment accumulation suggested that it was about the same order as, or less than, that of the water column (Nixon et al. 1984).

There appeared to be a near steady-state balance between nutrient inputs and outputs during the summer (1982) of our benthic flux measurements (Fig. 4). For both $\mathrm{N}$ and $\mathrm{P}$, concentration increases occurred in the water column during the summer in some of the tanks, representing an accumulation of about 4 to $8 \%$ of the input during that period. The range of water column combined $\left(\mathrm{PO}_{4}^{3-}+\mathrm{PP}\right)$ concentration measured during the summer bounded the effective delivery concentration; however, the combined (DIN + PN) concentration in some treatments fell below the expected value (Fig. 4). Seitzinger \& Nixon (in press) have estimated that a minimum of $16 \%$ of added $N$ was being lost from all tanks due to sediment denitrification activity in the first few months of the experiment. Gaseous N loss and/or a relative enrichment of $\mathrm{N}$ (over $\mathrm{P}$ ) in particles deposited to and retained within the sediments at high temperatures (Kelly 1983) could explain the slightly different behavior of $\mathrm{N}$ and $\mathrm{P}$ in some tanks.

A comparison of external and internal nutrient supply rates

Because the tanks approached steady-state the turnover of the mass of nutrients in the water column by

Table 6. Estimated annual water column retention of experimentally added nutrients. \% retention in the water column of nutrients added over approximately 1 yr (Jun 1981-Jun 1982), calculated as the amount, present in the water column as total nutrient in each treatment, in excess of the amount in the control tank in June 1982. This amount was compared to the amount added over that period to each treatment (see Table 1)

\begin{tabular}{|lcccccc|}
\hline & \multicolumn{6}{c|}{ Treatment } \\
\cline { 4 - 7 } & $1 \times$ & $2 \times$ & $4 \times$ & $8 \times$ & $16 \times$ & $32 \times$ \\
Nitrogen & $8.3 \%$ & $5.5 \%$ & $9.0 \%$ & $7.7 \%$ & $7.3 \%$ & $6.2 \%$ \\
Phosphorus & $7.6 \%$ & $4.8 \%$ & $4.9 \%$ & $6.8 \%$ & $10.0 \%$ & $6.7 \%$ \\
\hline
\end{tabular}


externally supplied sources was similar to the water turnover of the tank (Table 7). Thus, the average atom of each nutrient and each molecule of water entering the tank spent on the order of a month in the tank. In those instances where the $\mathrm{N}$ concentration was slightly below the effective input concentration, external $\mathrm{N}$ turnover was slightly faster than water turnover (Table 7).

A non-linear relation across the gradient between the concentration of water column nutrients (Fig. 3) and sediment fluxes (Fig. 1 \& 2) created an exponential decrease in the internal nutrient turnover rates with loading (Table 7, Fig. 5). The alteration in nutrient cycling was most dramatic in the case of nitrogen. For the control $(0 \times)$, the average atom of $N$ added to the water cycled between the water and sediments about 3.5 to 10 times during its approximately month-long passage through the tank. This cycling rate is similar to mid-Narragansett Bay during summer (Hale 1974, Kelly unpubl.). (Note: if the calculation were made using only dissolved inorganic $N$, the $0 \times$ turnover rate would approach $20 \mathrm{mo}^{-1}$; inclusion of $\mathrm{PN}$ is more influential on the calculation at lower loading rates because a higher proportion of the nutrients were contained in particles.) There were differences between the June and August situations - the internal $N$ cycle generally slowed down, relatively speaking, across the entire gradient over the summer where the water concentrations had increased slightly. On the average for the summer the internal delivery of $N$ to the water exceeded the external delivery only up until about $2 \times$ or $4 \times$ treatment (Fig. 6), or at input rates equivalent to about 2 to $5 \times 10^{3}$ mmols $\mathrm{N} \mathrm{m}^{-2}$ on an annual basis (Fig. 5). Below that delivery, benthic nitrogen recyc-
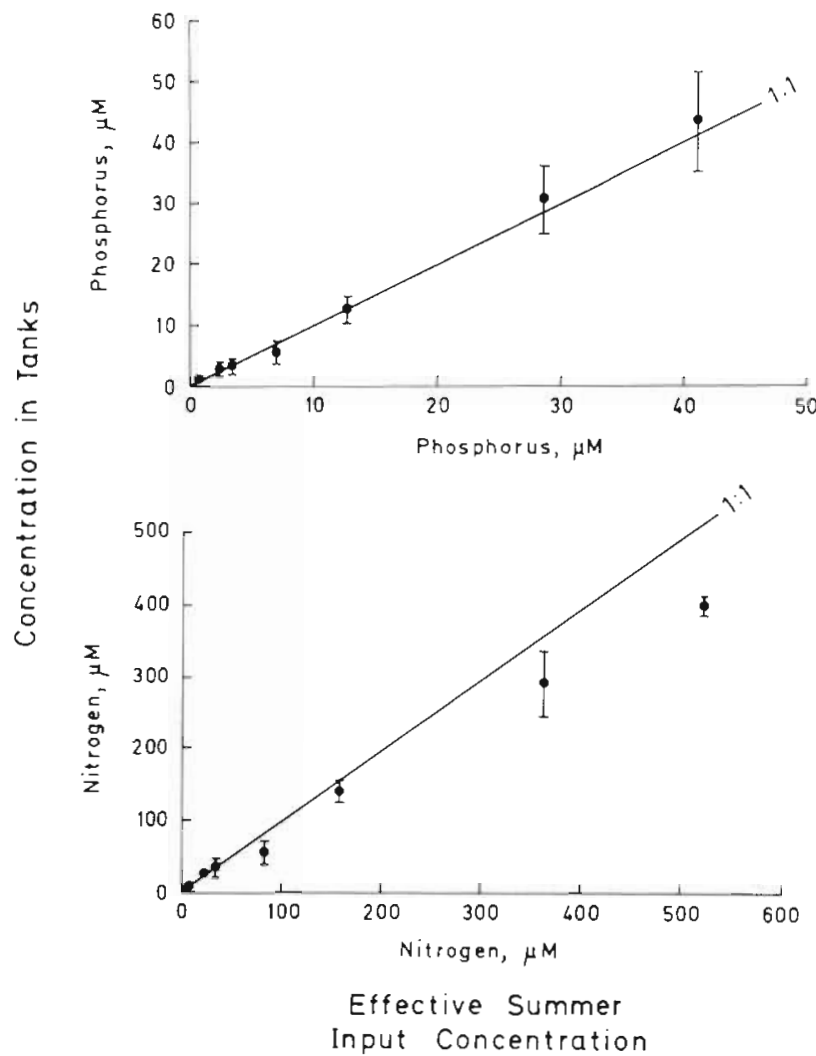

Fig. 4. Water column nutrient concentrations vs effective summer nutrient input concentrations. Effective input concentrations of $\mathrm{N}$ and $\mathrm{P}$ were calculated as the mass input from precipitation, flow, and experimental input over the $92 \mathrm{~d}$ summer period (Table 1), divided by the volume of water input over that same period. The point and bars for 1 control and 6 treatments represent the mean and range of June and August water column measurements for $\mathrm{DIN}+\mathrm{PN}$ and $\mathrm{PO}_{4}^{3-}$ $+\mathrm{PP}$. Lines are to indicate a $1: 1$ relation, indicating conservative behavior

Table 7 . Water and nutrient turnover rates by treament. Number of replacements of the water column water volume or nutrient mass by input from outside the tank (external) or from sediment feedback (internal) during the $92 \mathrm{~d}$ period $1 \mathrm{Jun}$ to $31 \mathrm{Aug} 1982$

\begin{tabular}{|c|c|c|c|c|c|}
\hline \multirow[b]{3}{*}{ Treatment } & \multicolumn{5}{|c|}{ Average turnover rate per $92 \mathrm{~d}$ summer period } \\
\hline & \multirow[t]{2}{*}{ Water $^{+}$} & \multicolumn{2}{|c|}{ Nutrients (External) ${ }^{++}$} & \multicolumn{2}{|c|}{ Nutrients (Internal) ${ }^{++}$} \\
\hline & & Nitrogen & Phosphorus & Nitrogen & Phosphorus \\
\hline $0 \times$ & 2.7 & 2.6 & 2.2 & 20.0 & 3.6 \\
\hline $1 \times$ & 2.8 & 3.0 & 2.6 & 5.0 & 2.9 \\
\hline $2 \times$ & 3.5 & 3.9 & 4.1 & 3.5 & 2.1 \\
\hline $4 \times$ & 2.7 & 4.3 & 3.8 & 2.6 & 2.9 \\
\hline $8 \times$ & 2.8 & 3.2 & 3.0 & 0.8 & 0.2 \\
\hline $16 \times$ & 2.4 & 3.0 & 2.3 & 2.0 & 0.9 \\
\hline $32 x$ & 3.3 & 4.3 & 3.2 & 0.2 & 0.02 \\
\hline \multicolumn{6}{|c|}{$\begin{array}{l}\text { + Calculated as (feedwater input volume/tank volume). Feedwater input was measured weekly. Note that the } \\
\text { average for the tanks was } 2.88( \pm 0.38) \text { for an average water residence time of } 31.9( \pm 3.9) \mathrm{d} \text {. Differences between } \\
\text { tanks are due to variations in flow delivery } \\
++ \text { Calculated as summer input of } \mathrm{N} \text { and } \mathrm{P} \text { (Table } 1 \text { ) divided by the mass in the water, determined from the average } \\
\text { concentration of } \mathrm{DIN}+\mathrm{PN} \text { or } \mathrm{PO}_{4}^{3-}+\mathrm{PP}(\mathrm{Table} 5) \\
+++ \text { Calculated as the integrated summer benthic release rate of } \mathrm{DIN} \text { or } \mathrm{PO}_{4}^{3-} \text { divided by mass in the water, determined } \\
\left.\text { from the average concentration of } \mathrm{DIN}+\mathrm{PN} \text { or } \mathrm{PO}_{4}^{3-}+\mathrm{PP} \text { (Table } 5\right)\end{array}$} \\
\hline
\end{tabular}




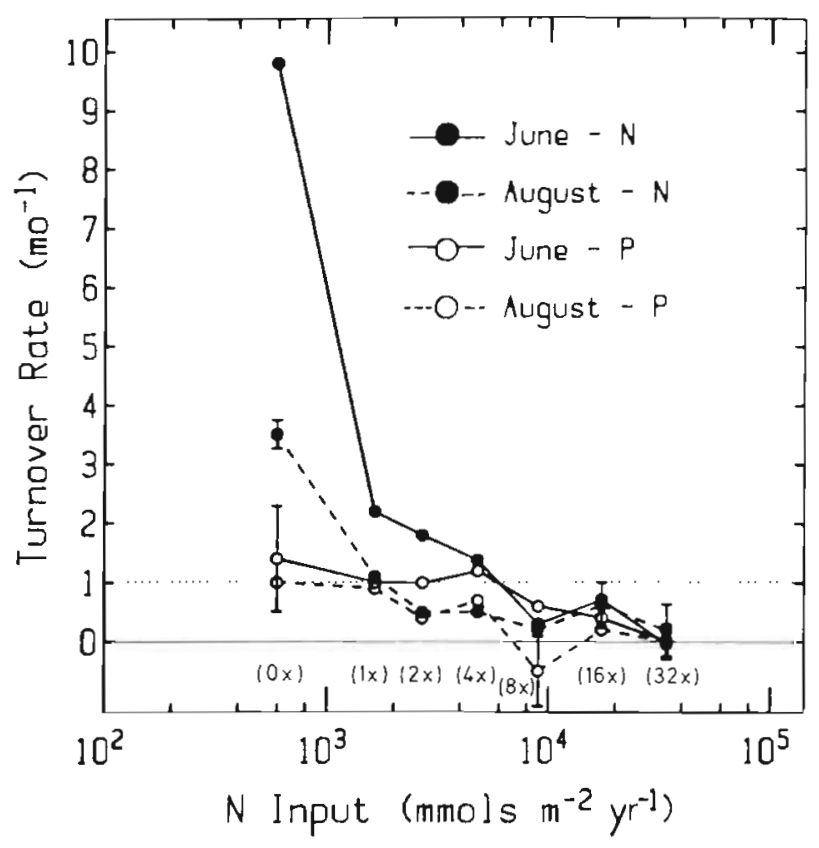

Fig. 5. Internal turnover rates of $\mathrm{N}$ and $\mathrm{P}$ during summer vs annual $N$ loading. The internal turnover rate (TR) was expressed per monthly $(30 \mathrm{~d})$ period. The dotted line at 1.0 (turnovers $\mathrm{mo}^{-1}$ ) indicates the approximate average water turnover rate for the tanks, which varied slightly among tanks (Table 7). Data points are for 1 control tank and 6 experimental treatments (designated along the $\mathrm{x}$-axis) for June and August. The bars indicate the range in calculated turnover ranges created by using the range for a given flux estimate instead of the mean, illustrating that the turnover rates changed significantly across the gradient in spite of the considerable uncertainty in flux estimates at higher treatments. Points without bars had TR range less than radius of the data point. The TR range includes the value of zero where the benthic flux was not significantly different from zero

ling thus seemed to play a more critical role in providing nitrogen for production in the water column. Above that delivery, the external load swamped the importance of the sediment-water cycle such that 'new' inputs determined the nitrogen concentrations in the water (Fig. 6).

Although phosphorus turnover rates also declined in a roughly exponential manner with loading, changes were less dramatic than with nitrogen. This is particularly true because of the difference between $\mathrm{N}$ and $\mathrm{P}$ in the unenriched control. As is usually the case in midNarragansett Bay in summer (Kremer \& Nixon 1978 , Nixon et al. 1980b, Nixon \& Pilson 1984), there was an excess of $P$ relative to $N$ in the water of the control tank. The DIN/PO $4_{4}^{3-}$ and (DIN $\left.+\mathrm{PN}\right) /\left(\mathrm{PO}_{4}^{3-}+\mathrm{PP}\right)$ ratios (atoms) were $5.1 \pm 2.2$ and $5.2 \pm 1.0(\overline{\mathrm{X}} \pm \mathrm{SD}$, $\mathrm{n}=3$ ), respectively, over the summer. The benthic flux N/P ratio was about 20 (Table 4 ); the flux relative to the concentration was richer in $N$ and therefore $P$ turnover was slower (Table 7, Fig. 5). The slower $P$ turnover could result from greater remineralization of
$P$ in the water before deposition (thus increasing the concentration and decreasing the flux), but in any event indicates a relative $N$ limitation in the water. An analogous situation, also indicative of $\mathrm{N}$-limitation, occurs in Narragansett Bay (Nixon et al. 1980b). From $0 \times$ to about $4 \times$, the internal turnover of $P$ was not very different from the water turnover. Thus, by mid-loading levels in the experiment, $N$ and $P$ turnovers became similar, and were slower than both water turnover and external turnover beyond the $4 \times$ treatment (Table 7, Fig. 5).

\section{Sediment-water interactions and eutrophication}

Based on the experimental results, we can suggest that the importance of benthic-pelagic interactions to several aspects of biogeochemical cycles in shallow coastal ecosystems will decrease as nutrient loading increases. Associated with this suggestion, there are
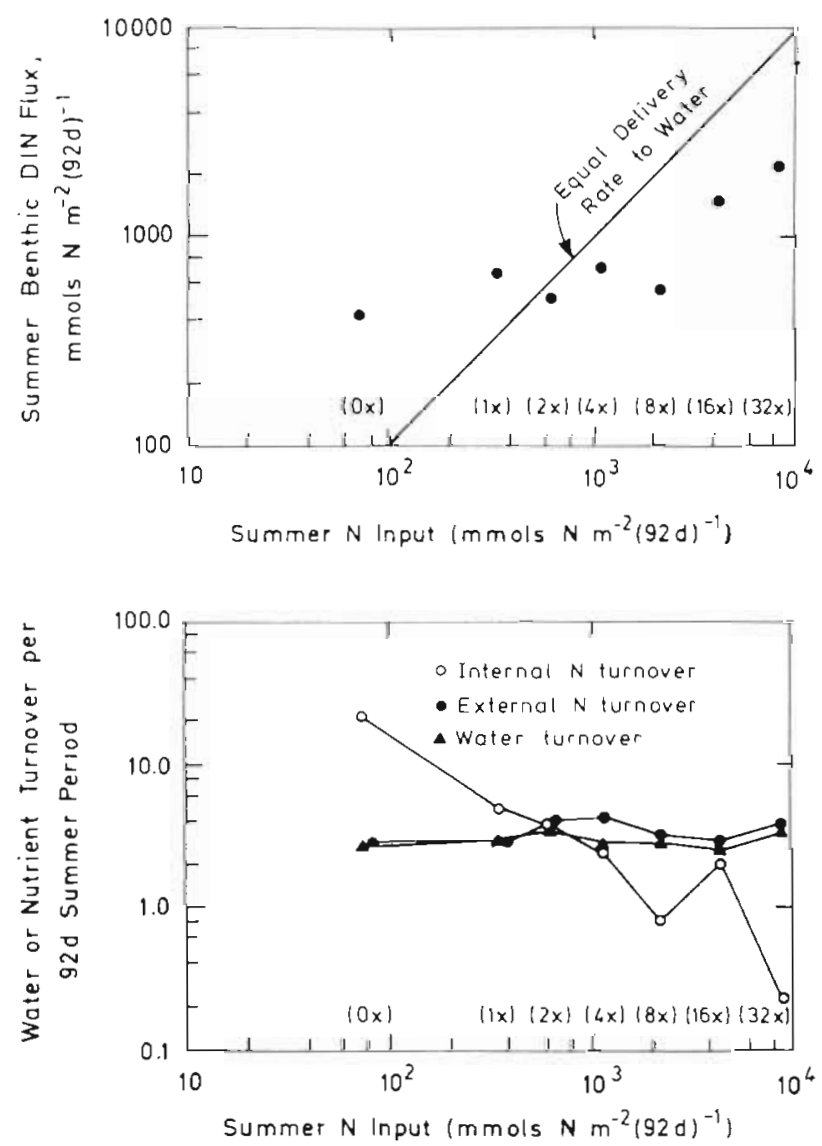

Fig. 6. Nitrogen flux, nitrogen turnover and water turnover vs summer nitrogen loading. Top: integrated summer benthic DIN flux (from average flux values, see Fig. 2 , using $n=2$ for $8 \times$ ), compared to integrated $\mathrm{N}$ input over the $92 \mathrm{~d}$ period. Line indicates isopleth where delivery of $\mathrm{N}$ to water column from external and internal sources is equal. Bottom: turnover rates vs summer $\mathrm{N}$ input. Data from Table 7 
ramifications for the fate and transport of many biologically active compounds. With regard to transport of $\mathrm{N}$ and $\mathrm{P}$ in particular, there is an interesting aspect to the comparison of systems experiencing different levels of external enrichment. Both enriched and unenriched coastal waters may exhibit nearly conservative flowthrough behavior with respect to nutrient mass, acting as poor nutrient 'sinks' even when differences in their internal biogeochemical cycles are quite pronounced. For example, in a relatively unenriched situation experiencing an external nutrient load (and flushing character) similar to Narragansett Bay, the average atom of external $\mathrm{N}$ added to the water column will take several trips to bottom sediments during its passage through the estuary towards the open sea because the sediment-water nutrient turnover rate exceeds the water turnover rate. In contrast, the average $\mathrm{N}$ atom added to a heavily enriched system, such as New York Harbor (like the $32 \times$ treatment), may never reach the sediments, but pass directly to the shelf ecosystem, mostly as dissolved inorganic nutrients, with water transport.

The results suggest we view changes in internal biogeochemical cycles to represent an ecological continuum - at one extreme, an ecosystem virtually dependent upon internal recycling processes, and at the other, an ecosystem with excessive, unutilized external nutrient delivery. Non-linear responses in rate processes (e.g. Fig. 2 \& 6) lend support to the notion that there are no lower thresholds for such change $e_{i}$ the most dramatic biogeochemical alterations from enrichment should be expected in the least enriched marine waters.

In spite of a continuum, a point can be reached where internal and external nutrient deliveries to the water column become equal. That situation occurs because net primary production, and thus the amount of organic matter available for heterotrophic remineralization, is non-linearly related to nutrient loading. Below this 'balance point', sediment recycling plays an important role in the system's nutrition. Low $\mathrm{N} / \mathrm{P}$ ratios of water column nutrients in many coastal ecosystems with relatively low loading rates suggest a phenomenon of relative $\mathrm{N}$ limitation (e.g. Boynton et al. 1982) and studies have suggested that sedimentwater interactions contribute to this limitation (cf Nixon et al. 1980b, Seitzinger et al. 1980, 1984, Nixon 1981). We need to conduct more whole-system experiments with carefully manipulated external supply nutrient ratios at low loading rates in order to fully identify the roles of both sediment and water column recycling in shallow coastal nutrient limitation.

Acknowledgements. We thank the entire MERL staff, as well as the graduate students and technicians, who participated in the eutrophication experiment. Kyle Kikuchi, Craig Doremus, and Betty Buckley helped with sampling and performed some of the laboratory analyses. Glenn Almquist did the ${ }^{14} \mathrm{C}$ productivity measurements under the direction of Percy Donaghay. Mike Meredith gave valuable advice on statistical methods. Primary funding for this research was provided by the Office of Research and Development. U.S. Environmental Protection Agency, under Cooperative Agreement No. CR 811060 . Additional funding was provided by Cornell University and by MERL. This publication is ERC-061 of the Ecosystems Research Center (ERC), Cornell University. The ERC was established in 1980 as a unit of the Center for Environmental Research at Cornell University. The work and conclusions published herein represent the views of the author(s), and do not necessarily represent the opinions, policies, or recommendations of the Environmental Protection Agency or of Cornell University. EPA and Cornell do not endorse any commercial products used in the study.

\section{LITERATURE CITED}

Aller, R. C. (1982). The effects of macrobenthos on chemical properties of marine sediment and overlying water In: McCall, P. L., Tevesz, M. J. S. (ed.) Animal-sediment relations. Plenum Press, New York, p. 53-102

Aller, R. C., Benninger, L. K. (1981). Spatial and temporal patterns of dissolved ammonium, manganese and silica fluxes from bottom sediments of Long Island Sound, U.S.A. J. mar. Res. 39: 295-314

Berounsky, V. M., Nixon, S. W. (in press). Eutrophication and the rate of net nitrification in a coastal marine ecosystem. Estuar. coast. Shelf. Sci.

Boynton, W R., Kemp, W. M., Keefe, C. W. (1980). Nutrient fluxes across the sediment-water interface in the turbid zone of a coastal plain estuary. In: Kennedy, V. S. (ed.) Estuarine perspectives. Academic Press, New York, p. $93-109$

Boynton, W. R., Kemp, W. M., Keefe, C. W. (1982). A comparative analysis of nutrients and other factors influencing estuarine phytoplankton production. In: Kennedy, V S. (ed.) Estuarine comparisons. Academic Press, New York, p. $69-90$

Elderfield, H., Bender, M., McCaffrey, R. J., Luedtke, N. (1981). Benthic flux studies in Narragansett Bay. Am. J. Sci. 281: $768-787$

Elmgren, R., Frithsen, J. B. (1982). The use of experimental ecosystems for evaluating the environmental impact of pollutants: a comparison of an oil spill in the Baltic Sea and two long-term, low-level oil addition experiments in mesocosms. In: Grice, G. D., Reeve, M. (ed.) Marine mesocosms: biological and chemical research in experimental ecosystems. Springer-Verlag, New York, p. 153-165

Furnas, M. J., Hitchcock, G. L., Smayda, T. J. (1976). Nutrientphytoplankton relationships in Narragansett Bay during the 1974 summer bloom. In: Wiley, M. (ed.) Estuarine processes, Vol. 1, Uses, stresses and adaptation to the estuary. Academic Press. New York, p. 118-134

Gleser, L. J (1982). Confidence regions for the slope in a linear errors-in-variables regression model. Tech. Rep. \#82-23. Dept. of Statistics, Purdue Univ.

Hale, S. S. (1974). The role of benthic communities in the nutrient cycles of Narragansett Bay. M. Sc. thesis, Univ. of Rhode Island, Kingston

Hargrave, B. T (1973). Coupling carbon flow through some pelagic and benthic communities. J. Fish. Res. Bd Can. 30: $1317-1326$ 
Henrickson, K., Hansen, J. I., Blackburn, T H. (1980). The influence of benthic infauna or exchange rates of inorganic nitrogen between sediment and water Ophelia, Supp. 1: $249-256$

Hunt, C. D. (1983). Variability in the benthic Mn flux in coastal marine ecosystems resulting from temperature and primary production. Limnol. Oceanogr 28: 913-923

Kelly, J. R. (1983). Benthic-pelagic coupling in Narragansett Bay. Ph. D. thesis, Univ. of Rhode Island, Kingston

Kelly, J. R. (1984). Microcosms for studies of sediment-water interactions. In: Persoone, G., Jaspers, E., Claus, C. (ed.) Ecotoxicological testing for the marine environment, Vol. 2. State Univ. Ghent and Inst. Mar. Scient. Res., Bredene, Belgium, p. 315-330

Kelly, J. R., Nixon, S. W (1984). Experimental studies of the effect of organic deposition on the metabolism of a coastal marine bottom community. Mar. Ecol. Prog. Ser. 17: $157-169$

Kemp, W. M. Wetzel, R. L., Boynton, W. R., D'Elia, C. F., Stevenson, J. C. (1982). Nitrogen cycling and estuarine interfaces: some current concepts and research directions. In: Kennedy, V. S. (ed.) Estuarine comparisons. Academic Press, New York, p. 209-230

Kremer, J., Nixon, S. W. (1978). A coastal marine ecosystem. Ecol. Stud. Vol. 24. Springer, Berlin

McCaffrey, R. J., Myers, A. C., Davey, E., Morrison, G., Ben$\operatorname{der}$ M., Luedtke, N., Cullen, D., Froelich, P., Klinkhammer, G. (1980). Benthic fluxes of nutrients and manganese in Narragansett Bay, Rhode Island. Limnol. Oceanogr. 25: $31-44$

Moran, P. A. P. (1971). Estimating structural and functional relationships. J. Multivar. Anal. 1: 232-255

Lambert, C. E., Oviatt, C. A. (1983). Manual of biological and geochemical techniques in coastal areas. Univ. of Rhode Island, Mar Tech. Rep. 86, p. 1-281

Nixon, S. W. (1981). Remineralization and nutrient recycling in coastal marine ecosystems. In: Nelson, B., Cronin, L. E. (ed.) Nutrient enrichment in estuaries. Humana Press, New Jersey, p. 111-138

Nixon, S. W (1983). Estuarine ecology - a comparative and experimental analysis using 14 estuaries and the MERL microcosms. Final report to U.S. EPA, Chesapeake Program under Grant No. X-003259-01

Nixon, S. W., Pilson, M. E. Q. (1983). Nitrogen in estuarine and coastal marine ecosystems. In: Carpenter, E. J., Capone, D. G. (ed.) Nitrogen in the marine environment. Academic Press, New York, p. 565-648

Nixon, S. W., Pilson, M. E. Q. (1984). Estuarine total system metabolism and organic exchange calculated from nutrient ratio: an example from Narragansett Bay. In: Kennedy, V. S. (ed.) The estuary as a filter. Academic Press, Orlando, p. 261-290

Nixon, S. W., Alonso, D., Pilson, M. E. Q., Buckley, B. A. (1980a). Turbulent mixing in aquatic microcosms. In: Giesy, J. P. (ed.) Microcosms in ecological research. DOE Symposium Series, Augusta, Georgia, Nov. 8-19, 1978, CONF 781101, National Technical Information Service, Springfield, Virginia, p. 818-849

Nixon, S. W., Kelly, J. R., Furnas, B. N., Oviatt, C. A., Hale, S. S. (1980b). Phosphorus regeneration and the metabolism of coastal marine bottom communities. In: Tenore, K. R.,
Coull, B. C. (ed.) Marine benthic dynamics. Univ. of South Carolina Press, Columbia, p. 219-242

Nixon, S. W., Oviatt, C. A., Hale, S. S. (1976). Nitrogen regeneration and the metabolism of coastal marine bottom communities. In: Anderson, J. M., Macfadyen, A. (ed) The role of terrestrial and aquatic organisms in decomposition processes. Blackwell Scientific Publishers, London, p. 269-283

Nixon, S. W., Pilson, M. E. Q., Oviatt, C. A., Donaghay, P., Sullivan, B., Seitzinger, S., Rudnick, D., Frithsen, J. (1984). Eutrophication of a coastal marine ecosystem - An experimental study using the MERL microcosms. In: M. J. R. Fasham (ed.) Proceedings of NATO Advanced Research Institute on: 'Flows of energy and materials in marine ecosystems: theory and practice.' Plenum, New York, p. 105-135

Oviatt, C., Buckley, B., Nixon, S. W. (1981). Annual phytoplankton metabolism in Narragansett Bay calculated from survey field measurements and microcosm abservations. Estuaries 4: 167-175

Oviatt, C. A., Frithsen, J., Gearing, J., Gearing, P. (1982). Low chronic additions of No. 2 fuel oil: chemical behavior, biological impact and recovery in a simulated estuarine environment. Mar. Ecol. Prog. Ser. 9: 121-136

Oviatt, C. A., Pilson, M. E. Q., Nixon, S. W., Frithsen, J. B., Rudnick, D. T., Kelly, J. R., Grassle, J. F., Grassle, J. P. (1984). Recovery of a polluted estuarine system: a mesocosm experiment. Mar. Ecol. Prog. Ser. 16: 203-217

Pamatmat, M. M. (1971). Oxygen consumption by the seabed. VI. Seasonal cycle of chemical oxidation and respiration in Puget Sound. Int. Revue ges. Hydrobiol. 56: 769-793

Pilson, M. E. Q., Vargo, G. A., Gearing, P., Gearing, J. N. (1977). The marine Ecosystems Research Laboratory; a facility for the investigation of effects and fates of pollutants. In: Proc. 2nd Natl Conf. on Interagency-Energy/ Environment R\&D Program, Washington, D.C. EPA 600/977-012, p. 513-516

Pilson, M. E. Q., Oviatt, C. A., Vargo, G. A., Vargo, S. L. (1979). Replicability of MERL microcosms: initial observations. In: Jacoff, F. S. (ed.) Advances in marine environmental research. Proc. of a Symp., 1977, EPA-600/9-79035 , p. $359-381$

Seitzinger, S. P., Nixon, S. W., Pilson, M. E. Q., Burke, S. (1980). Denitrification and $\mathrm{N}_{2} \mathrm{O}$ production in near-shore marine sediments. Geochim. cosmoschim. Acta 44: $1853-1860$

Seitzinger, S. P., Nixon, S. W., Pilson, M. E. Q. (1984). Denitrification and nitrous oxide production in a coastal marine ecosystem. Limnol. Oceanogr. 29: 73-83

Seitzinger, S. P., Nixon, S. W (in press). Eutrophication and the rate of denitrification and $\mathrm{N}_{2} \mathrm{O}$ production in coastal marine sediments. Limnol. Oceanogr.

Solorzano, L. (1969). Determination of ammonia in natural waters by the phenolhypochlorite method. Limnol. Oceanogr 14: 799-801

Strickland, J. D. H., Parsons, T. R. (1968). A practical handbook of seawater analysis. Bull. Fish. Res. Bd Can. 167: $1-311$

Valderrama, J. C. (1981). The simultaneous analysis of total nitrogen and total phosphorus in natural waters. Mar. Chem. 10: 109-122 